\title{
Dividend Policy and Institutional Holdings: Evidence from Australia
}

\author{
Thao Nguyen $(\mathbb{D})$ and Hui Li *(D) \\ Department of Economics and Finance, La Trobe Business School, La Trobe University, Melbourne 3083, \\ Australia; nhuthaosct@gmail.com \\ * Correspondence: m.li@latrobe.edu.au
}

Received: 20 November 2019; Accepted: 28 February 2020; Published: 3 March 2020

\begin{abstract}
This paper investigates the relationship between dividend payout and institutional ownership for all Australian listed firms in the period between 2001 and 2015. In our univariate tests, we find that institutional investors, in general, prefer dividend-paying firms more than non-paying firms, and for the dividend-paying firms in our sample, institutional investors hold more shares in the firms who pay higher dividends. We further explore the causality between dividend payout and institutional ownership in our multivariate tests with our panel data. The results show an insignificant effect of institutional ownership (dividend payout) on the future dividend payout (institutional ownership) while controlling for firms' fundamentals, that a higher dividend yield does not attract more institutional investors and that there is no catering to Australian institutional investors.
\end{abstract}

Keywords: dividend policy; institutional investor; Australian study; imputation tax system

JEL Classification: G30; G35

\section{Introduction}

Institutional investors hold a majority of share capital in Australian listed firms (RBA 2010). Institutional shareholders own more than $60 \%$ of the companies' stocks on average in our sample and should have some significant effects on the firms' dividend policy. (Jensen 1986) demonstrated that better monitoring brought by institutional investors is an incentive for firms to increase their dividend to attract more institutional investors. In this paper, we aim to investigate whether institutional ownership will have a positive effect on Australian firms' dividend payout and whether dividend clientele effect exists, namely if a higher dividend payout will increase institutional ownership subsequently. We examine these issues using a sample of 1140 Australian listed firms for the period between 2001 and 2015.

Most of the previous studies on the relationship between institutional ownership and dividend payout policy used the U.S. sample firms who operate under the classical tax system. Australia operates under the imputation tax system, which provides a unique opportunity to examine this relationship. Shareholders receive the cash dividend plus an imputation tax credit, and the tax credit can then be used to offset tax obligations on their income. Hence, the dividend payments could be more attractive than capital gain under certain circumstances. Prior research about the impact of dividends on institutional ownership is limited in Australia. Our study will make an incremental contribution to the literature regarding providing new empirical evidence in this research area with a relatively larger sample of Australian firms. Our research could also benefit the decision-makers, by advising them to use alternative distribution methods to the investors.

In this research, we propose two hypotheses. Our first hypothesis states that firms with larger institutional shareholdings will have higher dividend payout ratio, and our second hypothesis states 
that firms who pay a higher dividend will attract more institutional investors. Firstly, we find that Australian institutional ownership is not significantly affected by whether a firm pays dividends or not in the past, holding firm size, risk factor, market-to-book ratio, and other control variables constant. Furthermore, a higher dividend payout in the past does not attract more institutional investors in the future. Finally, we find that past institutional ownership has an insignificant effect on future dividend payout. Hence, dividend clientele effect toward institutional investors does not exist. By allowing current levels of institutional ownership to be influenced by past dividend payout and current levels of dividend to be influenced by past ownership simultaneously in the empirical specification, we can reduce the bias that could be caused by the endogenous relationship between institutional ownership and dividend payout; thus, providing reliable estimates ${ }^{1}$.

We subsequently divide our paper as follows. Section two summarizes the literature and proposes the hypotheses. Section three describes our data in detail and discusses the univariate tests in. Section four carries out the main empirical tests, and section five concludes this study.

\section{Literature Review and Hypotheses}

There is a large amount of research on the topic of dividend policy and researchers have taken many factors into account when investigating the purpose of paying dividends. One of the challenging issues is to understand why corporates distribute dividends and what determines the types of distributions (Allen and Michaely 2003). According to (John and Williams 1985), and (Miller and Rock 1985), the initial purpose of paying a dividend is to send a message about the firm's value to its shareholders. Based on the signal provided by the dividend, the potential investors can make their final investment decisions.

There are different groups of shareholders in a firm where conflicts are unavoidable between parties who have various rights and incentives. Thus, dividend plays an essential role in maintaining a smooth harmony between the company's stakeholders. According to (La Porta et al. 2000), dividends guarantee the relational distribution of earnings among investors and move firms' prosperity away from the controlling shareholders. Delivering regular dividend helps avoid a scenario where the firm's dominant shareholders control accumulated profits. (Fluck 1998, 1999) argued that dividend distribution could help solve disagreements between the insiders and outsiders of a firm. Institutional and retail shareholders, who receive different dividend incentives with their investment capital, are diversely informed about the firm's real value. Prior research has shown that dividends are employed to attract institutional investors because there is less dividend taxation on corporates. In contrast, individual shareholders suffered from the hefty tax on their received dividend.

(Allen et al. 2000) argued that institutional shareholders have more incentive to investigate firms' actual earnings status because they own a considerable volume of stocks and are inspired by the involvement of the firm management. As a result, institutional investors who take a significant part in corporate governance will receive more dividend as an encouragement for monitoring. According to (Jensen 1986), corporates have a willingness to pay more dividend to institutional shareholders who are superior monitors. Consistent with this idea, (Allen et al. 2000) argued that firms would encourage more institutional investment and their monitoring to enhance share prices. The authors also explained that the appearance of institutional shareholders symbolizes the high value of the firms because they are well informed about the firm' status, and only invest in growing firms. Hence, firm managers probably use high dividend as an incentive to entice institutional investors.

On the other hand, (Grinstein and Michaely 2005) show that while firms attempt to invite institutional investors by improving their dividend payout level, the higher dividends do not attract these investors. In addition, (Graham and Kumar 2006) pointed out that institutional investors pay their most attention to firms who have a lower dividend yield and share repurchases. This argument makes

1 In our panel data VAR regression, we also show an insignificant result between institutional ownership and dividend payout in the Granger causality test, reinforcing our main result. 
sense because institutional investors, who are known as informed investors, demand accumulated profits rather than just dividend alone.

Using a sample of U.S. firm, (Huang and Paul 2017) examined the relationship between institutional holdings and dividend policy by both considering investment style and firms' growth opportunities. They found that firms with low growth opportunities preferred high payout, and firms with high growth opportunities preferred low or no payout. (Jacob and J 2018) did a similar study for the Indian market, and they found that consistent with the evidence found in the U.S. market, institutional investors have more substantial holdings in dividend-paying firms and prefer dividend payers over nonpayers among larger firms. However, among smaller firms, institutional investors seem to prefer non-paying firms. They show no evidence supporting a positive relationship between total institutional ownership and payout level.

Taxes and imperfect market capital such as interest rate difference and transaction cost, in reality, inhibit individuals from a costless adjustment of their dividend forms to fit their preference patterns (i.e., dividend clienteles) or tax position (i.e., tax clientele) (Lee 2010). (Perez-Gonzalez 2003) supported the idea that catering to large shareholder does exist and found that the tax preference of shareholders who own most of the stocks of the firm can decide the firm's payout policy. For instance, if there is more tax advantage associated with the dividend, then the firms paid more dividend. (Ferreira et al. 2010) found that foreign institutional ownership is negatively associated with the likelihood that a firm pays dividends and the size of dividend payments by using a comprehensive data set of equity holdings from 37 countries over the years 2000-2007. The results support the existence of dividend clienteles around the world.

(Baker and Wurgler 2004a) proposed catering hypothesis which recommended that the dominant investors' requirement for the dividend paid determined a firm's dividend policy. Managers thus serve investors by delivering dividend when investors place a share price premium on the firm, and in contrast, by not distributing dividends when institutional investors desire for non-dividend. Research on catering hypothesis has been conventionally inspired by the effect of the major shareholders, especially institutional investors on dividend policy. There are numerous explanations for the case where managers possibly wish to cater their dividend strategies to expand the benefit of their dominant stockholders. For example, since the large stockholders hold a considerable fraction of the voting power in the firms, they can support the firms with their rapid and deliberated control and effectively communicate with the firms' board, therefore helping to resolve agency issues.

(Lee 2010) showed that dividend increases when it is taxed less, relative to capital gains for companies whose large stockholders are less controlled by the tax scheme. (Baker and Wurgler 2004b; $\mathrm{Li}$ and Lie 2006) showed that the catering theory has a considerable effect on corporate dividend policy. (Crane et al. 2016) showed that higher institutional ownership causes firms to pay more dividends. They identify a causal effect of institutional ownership on dividend policy based on the composition of the famous Russell indexes. Their estimates indicate that a one-percentage-point increase in institutional ownership causes a $\$ 7$ million $(8 \%)$ increase in dividends.

The research on the relationship between dividend policy and institutional investors is limited in Australia. Although retail shareholders do not own a large number of shares, they still play an essential role in corporate dividend decisions. According to (Lee 2010), retail shareholders are a determinant of dividend policy in Australia if they hold a considerable number of shares and other factors such as profitability, size, and financial leverage. Besides, the author stated that Australian corporates take individual shareholder preference for dividends seriously into account when making decisions for their dividend strategies. Catering to retail shareholders does exist in Australia.

Australia is a suitable candidate for examining firm dividend policy since its dividend imputation system decreases tax discouragement by paying out the dividend. The system entirely participates in personal and corporate tax rules. Corporate tax is imputed against personal taxation on the dividend paid, which eliminates the double-taxation problem associated with the classical tax scheme. Australia is also one of the developed countries which have applied the imputation tax system since July 1987 
(Cannavan et al. 2004). This tax system benefits retail shareholders, but is there any tax incentive for institutional investors? Also, overseas investors, in general, are no longer paying withholding tax when investing in Australian stocks (Bellamy 1994). Hence, the Australian tax system provides more tax incentive to domestic and international retail investors, with the Australian stock market also being an ideal opportunity for retail investors. In addition to the findings on the effect of retail shareholders on dividend policy in Australia, (Jun et al. 2011) found that institutional investors have put more weight in dividend-paying firms, and firms which have a full imputation tax credit.

Institutional and individual investors are different from each other in many aspects. According to (Allen et al. 2000), institutional shareholders have an impetus to inspect the firms' information as they do not want to take the risk for their large investment. It is reasonable to assume that firms will consider retail investors as less important than institutional investors. (Baker and Wurgler 2004a) catering hypothesis argued that dividends are determined by dominant investors who have more comprehension of the firms' circumstances. Thus, institutional shareholders may be a driving force for the firms' dividend policy. Institutional and individual investors also have distinct features concerning tax and regulation. Non-profit organizations and educational institutions may have lower tax duties or tax exemption, which may create an institutional tax clientele effect. Suppose that institutional investors are the better observers and that their monitoring ability and enticements will increase by their stock holdings, there should be a positive association between institutional ownership and dividend payout. Hence, we propose the first hypothesis as follows:

Hypothesis 1. (H1). All else unchanged, firms with larger institutional shareholdings will have higher dividend payout ratio.

We also consider the effect of dividend on institutional shareholdings. (Shleifer and Vishny 1986) argued that firms have a willingness to adjust their dividend policy to attract institutional investors. Allen et al. (2000) suggested that in a worst-case scenario, institutional investors are less likely to be taken to legal action if they own many shares from dividend-paying firms since the court would consider their investment as prudent. In addition, institutional investors have tax benefit as they are less taxed on dividends than individuals. Hence, firms have a stronger motivation to entice more institutional holdings.

Hypothesis 2. (H2). All else unchanged, firms who pay a higher dividend will attract more institutional investors.

\section{Data Description}

We collect a sample of 1140 Australian listed firms for the period between 2001 and 2015. Before 2001, data for each year are insufficient. We have dropped the firms whose industry code is financials or utilities. Our final sample includes 10,004 firm-year observations. We collect the top 20 institutional shareholdings from SIRCA (Securities Industry Research Centre of Asia-Pacific) ${ }^{2}$, as well as collecting firms' financial data from Data Analysis Premium, risk-free rates from Reserve Bank of Australia, and market index from the ASX (Australia Stock Exchange) website, respectively.

2 Different types of institutions have a different ability to collect and monitor information about the firms. Also, each category of investors also has different tax benefits. Ideally, to investigate the correlation between shareholdings and dividend, each group of investors should be analyzed separately. However, in our research, only the top 20 institutional shareholders are taken into account, resulting from the limitation to the Australian database. According to (Baker and Wurgler 2004a), dominant investors determine firms' dividend strategies. Thus, the top 20 institutional shareholdings would be an acceptable sample size for our research. SIRCA's ownership data comes from The MorningStar Company Ownership Data Collection. Morningstar Ownership data provides access to equity ownership information for over 1000 institutions in US, Australia and New Zealand by collecting portfolio holdings information on various types of investments, such as insurance products, mutual funds, pension funds, separate accounts, and more. 
Table 1 provides an overview of how institutional shareholdings are allocated across market capitalization quartiles. According to this table, the mean and the median of institutional ownership in the fourth quartile is the greatest. Median institutional ownership would be a better indicator of holdings than mean because it eliminates some outliers and provides the most accurate point of view. Median institutional ownership of the smallest cap group is about $62 \%$ of the firm's share, and around $73 \%$ of institutional holdings contribute to the largest firms' stocks. Thus, there is a trend that institutional investors prefer the large cap to small cap firms.

Because our sample period covers the Global Financial Crisis period, we divide the sample into three sub-periods, pre-GFC (Global Financial Crisis) (2001-2007), GFC (2008-2009), and post-GFC (2010-2015) to examine if there is a significant change in the institutional ownership across these three periods. As shown in the table, the trend of institutional investors preferring large cap firms over short cap firms is not only accurate for the whole period, but also for all sub-periods ${ }^{3}$. We also notice that over time, both mean and median of the institutional ownership has been slightly increasing, for example, the median has increased from $65.45 \%$ in the pre-GFC period to $69.38 \%$ in the post-GFC period.

(Grinstein and Michaely 2005) ${ }^{4}$, when analyzing the relationship between dividend policy and institutional ownership in the U.S. market, defined dividend as four times of the last quarterly dividend paid in the year divided by the book value of assets. However, we are only able to obtain annual dividend paid and book value of assets from Data Analysis Premium. Thus, the ratio of annual dividend to book value of assets at year-end would be our choice of dividend payout. We define the institutional ownership as the sum of the percentage of the shares held by the top 20 shareholders in a year. Our study would be more valid if all institutional holdings of the listed firms were available. However, as we can see in Table 1, the top 20 institutional shareholdings contribute to most of the listed firms' outstanding shares, and we expect that our data sample can sufficiently reveal most of the picture.

To further investigate the relationship between dividend payout and institutional ownership in Australia within this 15-year period, we divide the institutional shareholdings into groups by the firms' market cap quartiles. In our first test, we cluster institutional shareholdings into paying and non-paying groups for each market quartile formed annually. Then, we compute the mean and median institutional holdings for each group for the statistical $t$-tests. Table 2 presents the test results.

As can be seen from Table 2 Panel A, the number of non-dividend-paying firm-year observations (6057) outweighs that of dividend-paying firm-year (3947). This finding reveals that more than $50 \%$ of the Australian listed firms do not pay a dividend to their shareholders. In the non-dividend-paying group, there are more institutional holdings in the 3rd and 4th size quartile, while the institutional ownership in small-sized firms (the 1st and 2nd size quartile) is larger than that of big firms in the dividend-paying group. Both the mean and the median of paying firms are larger than that of the non-paying firms, and this pattern is consistent across all the size groups. As such, Allen et al. (2000) argument that institutional investors prefer paying to non-paying firms is valid in the case of Australian listed firms. We do $t$-test for the differences in the mean of the institutional ownership between the non-paying firms and the paying firms, across all the size groups and the full sample. We find that all the results are significant except the one for the 4th quartile, indicating overall that institutional investors hold more shares in dividend-paying firms than in non-paying firms. The result is also consistent with the prior studies in the U.S. market.

3 We thank an anonymous referee for the suggestion of dividing the sample into three sub-periods based on GFC.

4 Our research method primarily follows Grinstein and Michaely (2005) with some minor adjustments. 
Table 1. Institutional Ownership-Summary Statistics. This table reports aggregate institutional shareholdings across four market capitalization quartiles for the full sample and three sub-sample periods. Institutional ownership is the percentage of shares owned by the top 20 shareholders. The sample includes 1140 Australian listed firms and 10,004 firm-year observations for the period between 2001and 2015. We obtain the data from Securities Industry Research Centre of Asia-Pacific (SIRCA) and Data Analysis Premium respectively. We do not include financial companies and utility companies in the sample.

\begin{tabular}{|c|c|c|c|c|c|c|c|c|c|c|c|}
\hline \multirow[b]{2}{*}{$\begin{array}{c}\text { Market } \\
\text { Cap } \\
\text { Quartile }\end{array}$} & \multirow[b]{2}{*}{$\begin{array}{c}\text { Average } \\
\text { Market } \\
\text { Cap (\$M) }\end{array}$} & \multirow[b]{2}{*}{$\begin{array}{c}\text { Median } \\
\text { Market } \\
\text { Cap (\$M) }\end{array}$} & \multirow[b]{2}{*}{ Observations } & \multicolumn{2}{|c|}{ Full Sample } & \multicolumn{2}{|c|}{ 2001-2007 } & \multicolumn{2}{|c|}{ 2008-2009 } & \multicolumn{2}{|c|}{ 2010-2015 } \\
\hline & & & & $\begin{array}{c}\text { Mean } \\
\text { Institutional } \\
\text { Holdings }\end{array}$ & $\begin{array}{c}\text { Median } \\
\text { Institutional } \\
\text { Holdings }\end{array}$ & $\begin{array}{c}\text { Mean } \\
\text { Institutional } \\
\text { Holdings }\end{array}$ & $\begin{array}{c}\text { Median } \\
\text { Institutional } \\
\text { Holdings }\end{array}$ & $\begin{array}{c}\text { Mean } \\
\text { Institutional } \\
\text { Holdings }\end{array}$ & $\begin{array}{c}\text { Median } \\
\text { Institutional } \\
\text { Holdings }\end{array}$ & $\begin{array}{c}\text { Mean } \\
\text { Institutional } \\
\text { Holdings }\end{array}$ & $\begin{array}{c}\text { Median } \\
\text { Institutional } \\
\text { Holdings }\end{array}$ \\
\hline Lowest & 7.26 & 5.78 & 2506 & $61.21 \%$ & $61.53 \%$ & $60.22 \%$ & $60.28 \%$ & $60.72 \%$ & $61.14 \%$ & $62.68 \%$ & $63.04 \%$ \\
\hline 2 & 36.6 & 30.70 & 2499 & $61.91 \%$ & $63.18 \%$ & $60.57 \%$ & $61.90 \%$ & $61.34 \%$ & $61.23 \%$ & $63.89 \%$ & $65.17 \%$ \\
\hline 3 & 147.0 & 127.0 & 2503 & $66.82 \%$ & $69.15 \%$ & $66.16 \%$ & $68.88 \%$ & $66.34 \%$ & $67.72 \%$ & $67.87 \%$ & $70.33 \%$ \\
\hline Highest & 4040.0 & 979.0 & 2496 & $67.63 \%$ & $72.84 \%$ & $64.56 \%$ & $69.36 \%$ & $67.88 \%$ & $72.70 \%$ & $71.54 \%$ & $77.02 \%$ \\
\hline All & 1060 & 61.7 & 10004 & $64.39 \%$ & $67.01 \%$ & $62.88 \%$ & $65.45 \%$ & $64.07 \%$ & $65.93 \%$ & $66.49 \%$ & $69.38 \%$ \\
\hline
\end{tabular}

Table 2. Institutional Ownership and Dividend Payout. The data consist of publicly held Australian firms between 2001 and 2015 with information about institutional holdings and market value, excepting utility and financial companies. We obtain the top 20 Institutional-holdings data from SIRCA In Panel A, firms in each group are divided annually into those that pay dividends and those that do not pay dividends. The statistics in Panel A are for differences in means of institutional holdings between the size group that pays dividends and the size group that does not pay dividends. In Panel B, firms that pay dividends are divided annually into quartiles based on their dividend-to-book ratio. Groups are then aggregated across years and size quintiles. Statistics in Panel B are for differences in means of institutional holdings between the 4 th quartile and the 1 st quartile of dividend groups. The symbols $* * *, * *$ denote significance at the $10 \%, 5 \%$ and $1 \%$ levels, respectively.

\begin{tabular}{|c|c|c|c|c|c|c|c|}
\hline \multicolumn{8}{|c|}{ Panel A: Institutional Holdings (\%) Allocation in Dividend and Non-Dividend Paying Firms } \\
\hline & \multicolumn{3}{|c|}{ Paying } & \multicolumn{3}{|c|}{ Non-Paying } & \multirow{2}{*}{$\begin{array}{c}\text { Differences in Holdings: } \\
\text { Non-Paying vs. Paying } \\
t \text {-Test }\end{array}$} \\
\hline $\begin{array}{c}\text { Size } \\
\text { Quartile }\end{array}$ & $\begin{array}{l}\text { Mean Institutional } \\
\text { Holdings }\end{array}$ & $\begin{array}{c}\text { Median } \\
\text { Institutional } \\
\text { Holdings }\end{array}$ & No. & $\begin{array}{l}\text { Mean Institutional } \\
\text { Holdings }\end{array}$ & $\begin{array}{c}\text { Median Institutional } \\
\text { Holdings }\end{array}$ & No. & \\
\hline 1 & $71.83 \%$ & $74.26 \%$ & 221 & $60.18 \%$ & $60.07 \%$ & 2285 & $-8.18^{* * *}$ \\
\hline 2 & $69.98 \%$ & $72.65 \%$ & 620 & $59.25 \%$ & $60.14 \%$ & 1879 & $-11.39^{* * *}$ \\
\hline 3 & $69.62 \%$ & $71.74 \%$ & 1166 & $64.38 \%$ & $65.97 \%$ & 1360 & $-6.85^{* * *}$ \\
\hline 4 & $67.20 \%$ & $72.26 \%$ & 1940 & $64.38 \%$ & $66.20 \%$ & 1337 & 1.79 \\
\hline Total & $68.61 \%$ & $72.21 \%$ & 3947 & $61.64 \%$ & $63.09 \%$ & 6057 & $-16.40^{* * *}$ \\
\hline
\end{tabular}


Table 2. Cont.

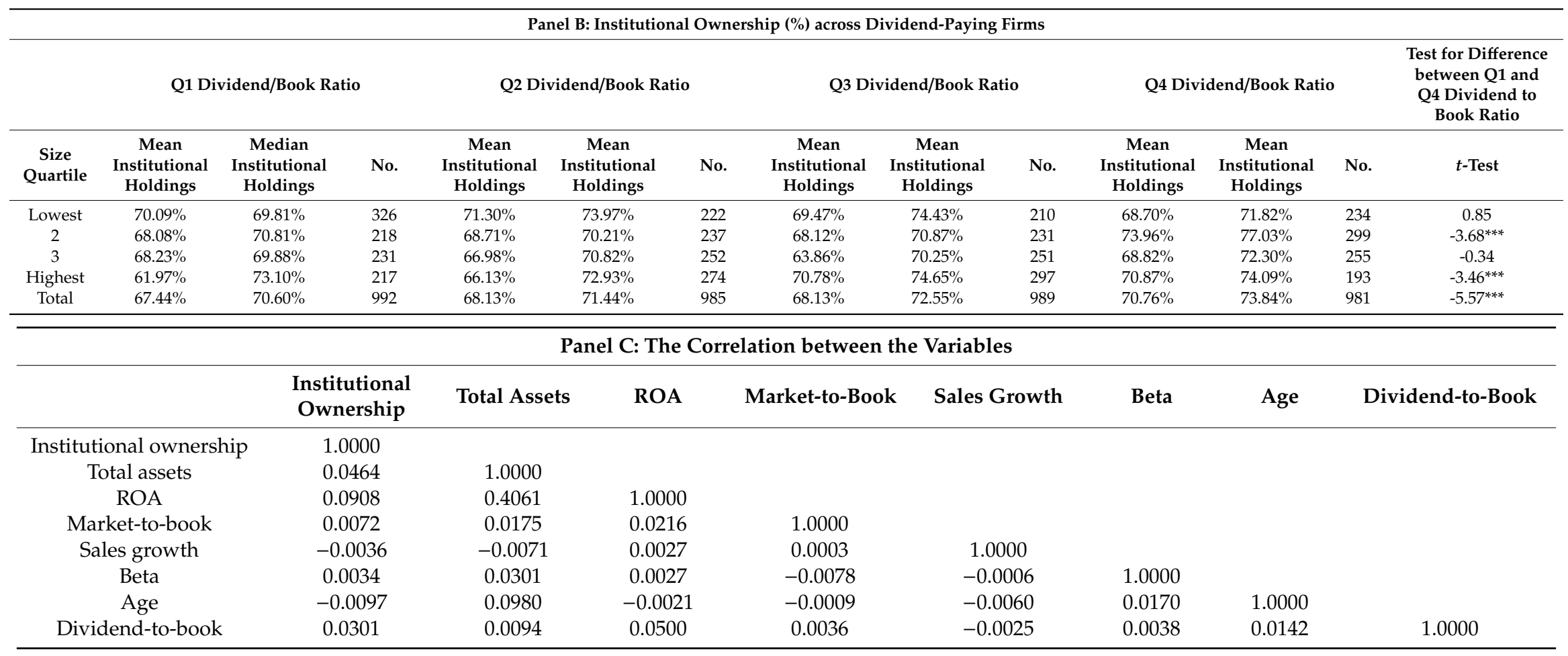


We make a further investigation of institutional dividend preference by analyzing allocations of institutional holdings among dividend-paying firms. We cluster firms' institutional holdings of each market cap quartiles into dividend-to-book quartiles formed annually. Table 2 Panel B reports our test result.

As shown in panel B of Table 2, the highest mean and median institutional holdings are in the 4th quartile of the dividend to book ratio. However, no clear pattern indicates that institutional investors prefer high dividend firms over low dividend firms. We do a $t$-test of the mean of the institutional ownership between the 1st quartile and the 4th quartile for all the four groups and the whole sample. We find that the results are mixed. For the whole sample, the institutional ownership is significantly higher in the 4th quartile that in the 1st quartile, indicating that institutional investors prefer high dividend overall. However, this result does not hold for the 2 nd and 4 th size quartile. Hence, our result is inconclusive and somewhat inconsistent with the finding by (Jun et al. 2011), who show that Australian firms have no preference on high dividend payout ratio because high dividend yield is not sustainable. Panel $C$ shows the correlation matrix between the variables of interest. The correlation coefficients are very low (except the correlation between total assets and ROA, which is 0.40 ), indicating the multicollinearity is not a concern in the following regression tests. Our overall result is weakly consistent with (Allen et al. 2000) argument that institutions prefer high dividend to low dividend. To summarize our univariate tests' results, Australian institutional investors prefer paying to non-paying firms. However, it is not necessarily true that they always prefer high dividend yield over low dividend yield under all circumstances.

In the next section, we are going to explore the effect of institutional holdings on dividend policy to test whether that higher institutional holding will subsequently increase firms' dividend payout level. We hypothesize the existence of dividend clientele toward institutional investors of Australian listed firms. We assume that it takes at least one year for institutional investors to affect the firms' dividend decision. In other words, institutional ownership at time $t-1$ can influence dividend payout level at time $t$. We also test the hypothesis that higher dividend will lead to a growth in institutional holdings.

\section{The Empirical Tests for the Hypotheses}

To investigate Hypothesis 1 that an increase in institutional holding at time $t-1$ will boost dividend payout at time $t$, we estimate our model with a panel data regression. Consistent with prior research (Grinstein and Michaely 2005), we use 'dividend-to-total assets' (Div/TA) as the measure of dividend payout level. In the regression, dividend plays the role of the dependent variable, while institutional holdings and other control variables are independent variables. Our control variables follow those that appear in the literature, including the natural logarithm of total assets, sales growth, return on assets (ROA) (or ROE), market-to-book ratios, beta, and the natural logarithm of firm age. We use the natural logarithm of total assets to control for the differences in firm size, ROA to control for firm profitability, sales growth over the last year, and market-to-book ratio to account for investment opportunities, the natural logarithm of firm age to account for differences in maturity across firms, and beta to control for firm's systematic risk. We calculate the beta of a firm by running a regression of the previous 36 monthly stock excess returns against the market excess returns, where the market return is measured with the ASX all ordinary index returns and the risk-free rate is the one-month rate on the government bill. We also control for industry-fixed (firm-fixed) and year-fixed effects in our panel data regression. The following equation is our baseline regression:

$$
\begin{gathered}
\text { Dividend to Total Assets } j_{j, t}=a+\beta \text { Institutional Holdings }_{j, t-1}+\gamma \sum \text { Control Variables }_{j, t-1} \\
+\sum \eta_{i} \text { Indsutry }_{i}\left(\sum \text { Firm }_{j}\right)+\sum \kappa_{t} \text { Year }_{t}
\end{gathered}
$$

where $j$ is the index for firms, $i$ is the index for an industry, $t$ is the index for time. Table 3 presents the result. 
Table 3. Effect of \% Institutional Holdings on Dividend. This table reports estimates of regressions of dividend payments on institutional holdings. Dividend-to-Book is the annual dividend in year $t$ divided by the book value of assets at the end of year $t$. Institutional ownership is the sum of the percentage of outstanding shares owned by the top 20 institutional investors. The control variables are as follows: Total assets is the natural log of total assets, Market-to-Book is the market value of equity to the book value of equity, ROA is the return on assets, sales growth is the one-year percentage change in sales, firm age is the natural logarithm of the firm's age, measured by the difference between the current year and the year when the firm was listed. We take all these financial variables from Data Analysis Premium. We calculate the beta of a firm by running a regression of the firm's previous 36 monthly stock excess returns against the market excess returns, where the market return is measured by the ASX all ordinary index returns, and the risk-free rate is the one-month rate on the government bill. The data consist of all Australian listed firms excluding financial or utility companies between 2001 and 2015. We obtain the institutional holdings data from SIRCA. Market indices are from the ASX website, and risk-free rates are from the Australia Reserve Bank website. In model (1), we control for industry-fixed and year-fixed effect. In model (2), we control for firm-fixed and year-fixed effect. The standard errors are clustered at the firm level. The symbols ${ }^{*} * *, * * *$ denote significance at the $10 \%, 5 \%$, and $1 \%$ levels, respectively.

\begin{tabular}{|c|c|c|}
\hline \multirow[b]{2}{*}{ Explanatory Variables } & \multicolumn{2}{|c|}{ Dividend-to-Book $t$} \\
\hline & (1) & (2) \\
\hline Institutional Ownership $t-1$ & $\begin{array}{c}0.00281 \\
(0.00251)\end{array}$ & $\begin{array}{c}-0.000649 \\
(0.00278)\end{array}$ \\
\hline Total Assets $t-1$ & $\begin{array}{c}\mathbf{0 . 0 0 1 4 8}^{* * *} \\
(0.000342)\end{array}$ & $\begin{array}{c}0.000321 \\
(0.000499)\end{array}$ \\
\hline $\mathrm{ROA}_{t-1}$ & $\begin{array}{c}\mathbf{0 . 0 0 8 0 8} * * * \\
(0.00134)\end{array}$ & $\begin{array}{c}\mathbf{0 . 0 0 6 7 6} * * * \\
(0.00129)\end{array}$ \\
\hline Market to Book $\mathrm{t}_{-1}$ & $\begin{array}{c}\mathbf{0 . 0 0 0 9 5 9} * * * \\
(0.000181)\end{array}$ & $\begin{array}{c}\mathbf{0 . 0 0 0 8 0 7} * * * \\
(0.000174)\end{array}$ \\
\hline Sales Growth $t_{-1}$ & $\begin{array}{c}-\mathbf{0 . 0 0 0 0 2 4 6} * \\
(0.0000145)\end{array}$ & $\begin{array}{c}-0.0000205 \\
(0.000017)\end{array}$ \\
\hline Beta $_{t-1}$ & $\begin{array}{c}-0.00111 \\
(0.000748)\end{array}$ & $\begin{array}{l}-0.00201 \\
(0.00146)\end{array}$ \\
\hline Firm Age $t_{-1}$ & $\begin{array}{c}-0.00111 \\
(0.000748)\end{array}$ & $\begin{array}{c}-0.00164 \\
(0.00137)\end{array}$ \\
\hline Industry fixed & Yes & No \\
\hline Firm fixed & No & Yes \\
\hline Year fixed & Yes & Yes \\
\hline Observations & 8956 & 8956 \\
\hline R-Square (between) & $24.63 \%$ & $14.69 \%$ \\
\hline
\end{tabular}

The coefficients on the top 20 institutional holdings are insignificant in both models, one is positive, and the other is negative, indicating that the prior institutional ownership is not significantly associated with future dividend payments. The coefficients on $\mathrm{ROA}^{5}$ and market-to-book are both positive and significant, indicating that higher profitability and growth opportunity are associated with a greater dividend yield in the future. The coefficients on total assets are found positive with one significant result, indicating that in general, larger firms pay more dividend in the future. In contrast, the coefficients on beta and sales growth are negative in both models with just one being marginally significant. This result may indicate that the higher the beta, which represents a higher systematic

5 We also use ROE and adjusted ROA (ratio of EBIT to TA) as the alternative measurements for profitability and find that the result is similar. 
firm risk, the lower the dividend is paid in the future, though the impact is not significant. Higher sales growth rate reducing the future dividend payment is somewhat surprising though the impact of sales growth on the dividend is shown to be less significant than that of market-to-book, which also captures the growth opportunity. To provide the main view on what we have discovered from the regression, the effect of past institutional holdings on the future dividend is insignificant. This result does not support Hypothesis 1 and could demonstrate that during the period between 2001 and 2015, Australian firms did not tend to cater to their institutional investors by increasing their dividend level.

We next test our Hypothesis 2 of whether the past dividend policy will affect the future institutional shareholdings. We use institutional holdings as the dependent variable, while pay/no-pay dummy or dividend-to-book variable as the independent variables, holding other control variables same. Our model follows the specification below, and Table 4 reports the estimation result.

$$
\begin{aligned}
& \text { Institutional Holdings } s_{j, t}=a+\beta \text { Dividend to Total Assets } s_{j, t-1}\left(\text { PaynopayDummy }_{j, t-1}\right) \\
& +\sum \lambda \text { Control Variables }_{j, t-1}+\sum \eta_{i} \text { Indsutry }_{i}\left(\sum \text { Firm }_{j}\right)+\sum \text { Year }_{t}
\end{aligned}
$$

As shown in Table 4, in both models, the coefficients on the dividend yield and the dummy variable for dividend payment are insignificant and negative, meaning that institutional investors probably dislike higher dividend payments or are at least not attracted by a higher dividend yield or whether the firm has a history of dividend payments in the past. This finding does not match our univariable test result. In other words, dividend decisions in the past have a trivial effect on current institutional investment decisions. In both models, firm age and firm size seem to play an essential role for institutional investors' investment decision because only the coefficients on these two variables are significant after controlling other fundamentals. Firm size is significantly and positively associated with future institutional shareholdings indicating that larger firms are more attractive to institutional investors. Firm age is significantly and negatively related to future institutional shareholdings, and this result could be explained by the fact that young firms may have a higher growth prospectus than old firms and thus are preferred by institutional investors who seek capital gains rather than dividends in the future. All other control variables are insignificant in both models.

In order to address the potentially endogenous relationship between institutional ownership and dividend payout policy ${ }^{7}$, we estimate a panel vector auto-regression (VAR) system of equations of institutional holdings and dividend payout for the sample of dividend-paying firms. The system of equations is specified as follows:

$$
\begin{aligned}
& \text { Institutional Holdings } s_{j, t}=a+\beta \text { Institutional Holdings } s_{j, t-1} \\
& +\gamma \text { DividendtoTotalAssets }_{j, t-1}+\sum \text { Indsutry }_{i}+\sum Y \text { ear } \\
& \text { DividendtoTotalAssets }_{j, t}=a+\beta \text { Institutional Holdings } s_{j, t-1} \\
& +\gamma \text { DividendtoTotalAssets } \\
& j, t-1+\sum \text { Indsutry }_{i}+\sum Y e a r
\end{aligned}
$$

Equation (1) captures the effect of past institutional holdings and past dividend on the institutional ownership at time $t$. Equation (2) captures the influence of past institutional holdings and dividend on the dividend at time $t$. The number of lags should first be decided. We hold an assumption that it takes at least one year for institutional holdings to affect dividend and vice versa. The assumption has been validated by the result of our test for the optimal number of lags of the variables in the system $^{8}$. Table 5 describes how dividend and institutional holdings are affected jointly by their past values. In our specification, we use one lag of institutional ownership and one lag of dividend yield

6 We have also used the firm-fixed effect in the regression and the result is similar but with a low $\mathrm{R}$ square.

7 We acknowledge that the VAR system of regressions might not be a perfect solution to the potential endogeneity concerns. A natural experiment such as shown by (Crane et al. 2016) might be better.

8 To save space, we don't report the result in the paper, but it will be available upon request. 
as the instrumental variables. As shown in Panel A and Panel B, the coefficients of the lag of the dividend payout (institutional ownership) are not significantly associated with the current institutional ownership (dividend payout). The result from the Granger causality test also shows that neither the dividend payout causes institutional ownership, nor the institutional ownership causes dividend payout, reinforcing our conclusion from the panel VAR estimation that there is no significant impact of the past values of these two variables on their future values.

Table 4. Effect of Pay/No Pay Decision and Dividend Ratio on Institutional Holdings. This table reports estimates of regressions of institutional holdings on lagged dividend payments or a dummy variable that indicates whether a firm has paid a dividend in the last year. Dividend-to-Book is the annual dividend in year $t$ divided by the book value of assets at the end of year $t$. Institutional ownership is the sum of the percentage of shares outstanding owned by the top 20 institutional investors. The control variables are as follows: Total assets is the natural log of total assets, Market-to-Book is the market value of equity to the book value of equity, ROA is the return on assets, sales growth is the one-year percentage change in sales, firm age is the natural logarithm of the firm's age, measured by the difference between the current year and the year when the firm was listed, PayDum is equal to 1 if a firm has paid a dividend in the last year and 0 otherwise, all these financial variables are taken from Data Analysis Premium. We calculate the beta of a firm by running a regression of the firm's previous 36 monthly stock excess returns against the market excess returns, where the market return is measured by the ASX all ordinary index returns and the risk-free rate is the one-month rate on the government bill. The data consist of all Australian listed firms excluding financial or utility companies between 2001 and 2015. We obtain institutional-holdings data from SIRCA. Market indices are from the ASX website and risk-free rates are from the Australia Reserve Bank website. In both models, we control for industry-fixed and year-fixed effect ${ }^{6}$. The standard errors are clustered at the firm level. The symbols ***,*** denote significance at the $10 \%, 5 \%$, and $1 \%$ levels, respectively.

\begin{tabular}{|c|c|c|}
\hline \multirow[b]{2}{*}{ Explanatory Variables } & \multicolumn{2}{|c|}{ Institutional Ownership $\mathrm{t}$} \\
\hline & (1) & (2) \\
\hline Total Assets $t-1$ & $\begin{array}{c}\mathbf{0 . 0 0 7 9 0} * * * \\
(0.00276)\end{array}$ & $\begin{array}{c}\mathbf{0 . 0 0 7 3 3} * * * \\
(0.00280)\end{array}$ \\
\hline $\mathrm{ROA}_{t-1}$ & $\begin{array}{c}0.00326 \\
(0.00676)\end{array}$ & $\begin{array}{c}0.00372 \\
(0.00683)\end{array}$ \\
\hline Market to Book $_{t-1}$ & $\begin{array}{c}0.000638 \\
(0.000730)\end{array}$ & $\begin{array}{c}0.000672 \\
(0.000736)\end{array}$ \\
\hline Sales Growth $t$ & $\begin{array}{l}0.0000171 \\
(0.000063)\end{array}$ & $\begin{array}{l}0.0000187 \\
(0.000063)\end{array}$ \\
\hline Beta $t-1$ & $\begin{array}{l}-0.00119 \\
(0.00153)\end{array}$ & $\begin{array}{l}-0.00117 \\
(0.00153)\end{array}$ \\
\hline Firm Age $t-1$ & $\begin{array}{c}-0.0174 * * * \\
(0.00495)\end{array}$ & $\begin{array}{c}-\mathbf{0 . 0 1 7 5} * * * \\
(0.00522)\end{array}$ \\
\hline PayDum $_{t-1}$ & $\begin{array}{l}-0.00833 \\
(0.00742)\end{array}$ & \\
\hline $\operatorname{DivTa}_{t-1}$ & & $\begin{array}{c}-0.0363689 \\
(0.0638)\end{array}$ \\
\hline Industry fixed & Yes & Yes \\
\hline Firm fixed & No & No \\
\hline Year fixed & Yes & Yes \\
\hline Observations & 8956 & 8956 \\
\hline R-Square (between) & $9.05 \%$ & $9.02 \%$ \\
\hline
\end{tabular}


Table 5. Panel Vector Autoregressive Regression. This table reports the results of the panel vector-autoregressive regressions. In the regressions, DivTa is the ratio of dividend to total assets. The variable institutional ownership is the sum of the percentage holdings of the top 20 institutional investors. Industry-fixed and year-fixed effects are included. The standard errors are clustered at the firm level. The sample consists of 3947 firm-year observations for Australian listed firms that paid dividends from 2001 until 2015. The estimates in Panels A and B present the coefficients on the variables and panel $\mathrm{C}$ reports the result from the Granger causality test.

\begin{tabular}{|c|c|c|c|c|}
\hline \multicolumn{5}{|c|}{ Panel Var Regression with One Lag } \\
\hline \multicolumn{5}{|c|}{ Panel A: Effect of Dividend Payout on Institutional Holdings } \\
\hline & Coefficient & Standard Error & $\mathbf{z}$ & $\mathbf{P}>\mathbf{z}$ \\
\hline \multicolumn{5}{|l|}{ Institutional ownership $t$} \\
\hline Institutional ownership $t-1$ & 0.610239 & 0.068826 & 8.87 & 0 \\
\hline DivTa $t_{-1}$ & -0.02905 & 0.094185 & -0.31 & 0.758 \\
\hline \multicolumn{5}{|c|}{ Panel B: Effect of Institutional Holdings on Dividend Payout } \\
\hline \multicolumn{5}{|l|}{ DivTa $t$} \\
\hline Institutional ownership $t-1$ & -0.00692 & 0.01204 & -0.57 & 0.566 \\
\hline DivTa $t_{-1}$ & 0.645867 & 0.080772 & 8 & 0 \\
\hline \multicolumn{5}{|c|}{ Panel C: Granger Causality Test } \\
\hline & & chi2 & & P > chi2 \\
\hline \multicolumn{5}{|l|}{ Institutional ownership } \\
\hline DivTa & & 0.095 & & 0.758 \\
\hline All & & 0.095 & & 0.758 \\
\hline \multicolumn{5}{|l|}{ DivTa } \\
\hline Institutional ownership & & 0.330 & & 0.566 \\
\hline All & & 0.330 & & 0.556 \\
\hline
\end{tabular}

To summarize, the result from the panel VAR estimate suggests that Australian institutional investors have no preference for high dividend yield. Hence, we can reject Hypothesis 2 that there is a positive effect of dividend on institutional holdings. We can also reject Hypothesis 1 that there is a positive effect of institutional holdings on future dividend payout. The findings do not support the idea that the dividend clientele exists in Australia.

\section{Discussion and Conclusions}

(Baker and Wurgler 2004a) suggested that the catering theory of dividend of dominant investors influencing the firms' payout policy. (Jensen 1986) pointed out that an increase in institutional holdings may lead to a higher dividend payout and help reduce agency problems arising from excessive free cash flows. As a result, firms have had the motivation to increase their dividend level to attract more institutional investors (Allen et al. 2000). We test the dividend clientele and catering theory in our paper by examining the relationships between dividend and institutional holdings of 1140 Australian listed firms from 2001 to 2015.

Our univariate tests show that institutional investors are more likely attracted by big-cap than by small-cap firms. There is a trend of institutional investors preferring large cap firms over short cap firms. We also notice that over time, both mean and median of the institutional ownership has been slightly increasing, for example, the median has increased from $65.45 \%$ in the pre-GFC period to $69.38 \%$ in the post-GFC period. We also find that institutional investors prefer paying firms to non-paying firms, both the mean and the median of paying firms are larger than that of the non-paying firms, and this pattern is consistent across all the size groups which is consistent with (Allen et al. 2000) argument. However, institutional ownership is not universally increasing with dividend yield when we examine this relationship with the sample of dividend-paying firms. We do a $t$-test of the mean of the institutional ownership between the 1st quartile and the 4th quartile for all the four dividend-paying groups 
and the whole sample. We find that the results are mixed. For the whole sample, the institutional ownership is significantly higher in the 4th quartile that in the 1st quartile, indicating that institutional investors prefer high dividend overall. However, this result does not hold for the 2nd and 4 th size quartile. This finding, in general, is consistent with the (Grinstein and Michaely 2005) study with the U.S. data. This result could be explained by the theory of which a high dividend yield is not stable (Jun et al. 2011).

According to (Jensen 1986), firms tend to pay more dividend to diminish agency conflicts and increase their stock values, which increases institutional holdings. However, the results from our multivariate tests do not support this theory. The coefficients on the top 20 institutional holdings are insignificant in our empirical tests, one is positive, and the other is negative, indicating that the prior institutional ownership is not significantly associated with future dividend payments. Higher institutional holdings do not lead to a higher dividend in the future. This finding shows that dividend clientele toward institutional investors does not exist in the case of Australian listed firms. We also find that higher dividend does not subsequently boost institutional holdings. The coefficients on the dividend yield and the dummy variable for dividend payment are insignificant and negative in our empirical test, meaning that institutional investors probably dislike higher dividend payments or are at least not attracted by a higher dividend yield or whether the firm has a history of dividend payments in the past. This result may be explained by (Jun et al. 2011) statement that a high dividend yield is considered non-sustainable by institutional investors. The estimation results from the panel VAR regression and the Granger causality test also show no significant influences between institutional ownership and dividend payout. After taking other fundamentals into account, the dividend does not seem to be a critical factor for the institutional investors in their decision-making.

Overall, our empirical results suggest that the dividend payout seems not be a critical factor in the determination of the institutional ownership in Australia. For the recommendation of future studies on this topic, one of the interest areas is the association between institutional shareholdings and distribution methods other than dividend payment, such as share repurchases. We conjecture that there could be a positive and significant relationship between institutional holdings and share repurchases of Australian listed firms. The firms who do not pay cash dividend could satisfy their institutional investors by share repurchases.

Author Contributions: T.N. has done the data collection and some preliminary empirical tests and wrote the first draft. H.L. revised the paper and conducted the final empirical work. All authors have read and agreed to the published version of the manuscript.

Funding: This research received no external funding.

Conflicts of Interest: The authors declare no conflict of interest.

\section{References}

Allen, Franklin, Antonio E. Bernardo, and Ivo Welch. 2000. A theory of dividends based on tax clienteles. The Journal of Finance 55: 2499-536. [CrossRef]

Allen, Franklin, and Roni Michaely. 2003. Payout policy. In Handbook of the Economics of Finance. Vol. 1A: Corporate Finance. Edited by George Constantinides, Milton Harris and Rene Stulz. Amsterdam: Elsevier, pp. 337-429.

RBA. 2010. Australian Bureau of Statistics; Sydney: RBA. Available online: https:/www.rba.gov.au/publications/ bulletin/2010/sep/4.html (accessed on 27 February 2020).

Baker, Malcolm, and Jeffrey Wurgler. 2004a. A catering theory of dividends. The Journal of Finance 59: 1125-65. [CrossRef]

Baker, Malcolm, and Jeffrey Wurgler. 2004b. Appearing and disappearing dividends: The link to catering incentives. Journal of Financial Economics 73: 271-88. [CrossRef]

Bellamy, David E. 1994. Evidence of imputation clienteles in the Australian equity market. Asia Pacific Journal of Management 11: 275-87. [CrossRef]

Cannavan, Damien, Frank Finn, and Stephen Gray. 2004. The value of dividend imputation tax credits in Australia. Journal of Financial Economics 73: 167-97. [CrossRef] 
Crane, Alan D., Sébastien Michenaud, and James P. Weston. 2016. The Effect of Institutional Ownership on Payout Policy: Evidence from Index Thresholds. The Review of Financial Studies 29: 1377-408. [CrossRef]

Ferreira, Miguel A., Massimo Massa, and Pedro Matos. 2010. Dividend Clienteles around the World: Evidence from Institutional Holdings. Working Paper FBE 35-09. Los Angeles, CA, USA: The University of Southern California. Available online: https://papers.ssrn.com/sol3/papers.cfm?abstract_id=1447573 (accessed on 21 September 2018).

Fluck, Zsuzsanna. 1998. Optimal financial contracting: Debt versus outside equity. Review of Financial Studies 11: 383-418. [CrossRef]

Fluck, Zsuzsanna. 1999. The dynamics of the management-shareholder conflict. Review of Financial Studies 12: 379-404. [CrossRef]

Graham, John R., and Alok Kumar. 2006. Do dividend clienteles exist? Evidence on dividend preferences of retail investors. The Journal of Finance 61: 1305-36. [CrossRef]

Grinstein, Yaniv, and Roni Michaely. 2005. Institutional holdings and payout policy. The Journal of Finance 60: 1389-426. [CrossRef]

Huang, Wei, and Donna L. Paul. 2017. Institutional Holdings, Investment Opportunities and Dividend Policy. The Quarterly Review of Economics and Finance 64: 152-61. [CrossRef]

Jacob, Chacko, and Jijo Lukose P. J. 2018. Institutional Ownership and Dividend Payout in Emerging Markets: Evidence from India. Journal of Emerging Market Finance 17: S54-82. [CrossRef]

Jensen, Michael C. 1986. Agency costs of free cash flow, corporate finance, and takeovers. The American Economic Review 76: 323-29.

John, Kose, and Joseph Williams. 1985. Dividends, dilution and taxes: A signaling equilibrium. Journal of Finance 40: 1053-70. [CrossRef]

Jun, Aelee, David R. Gallagher, and Graham H. Partington. 2011. Institutional dividend clienteles under an imputation tax system. Journal of Business Finance and Accounting 38: 198-224. [CrossRef]

La Porta, Rafael, Florencio Lopez-de-Silanes, Andrei Shleifer, and Robert W. Vishny. 2000. Agency problems and dividend policies around the world. The Journal of Finance 55: 1-33. [CrossRef]

Lee, King Fuei. 2010. Retail minority shareholders and corporate reputation as determinant of dividend policy in Australia. Pacific-Basin Finance Journal 18: 351-68. [CrossRef]

Li, Wei, and Erik Lie. 2006. Dividend changes and catering incentives. Journal of Financial Economics 80: 293-308. [CrossRef]

Miller, Merton H., and Kevin Rock. 1985. Dividend policy under asymmetric information. The Journal of Finance 40: 1031-51. [CrossRef]

Perez-Gonzalez, Francisco. 2003. Large Shareholders and Dividends: Evidence from U.S. Tax Reforms. Columbia University Graduate School of Business Working Paper Series. New York: Columbia University Graduate School Business.

Shleifer, Andrei, and Robert W. Vishny. 1986. Large Shareholders and Corporate Control. The Journal of Political Economy 94: 461-88. [CrossRef]

(C) 2020 by the authors. Licensee MDPI, Basel, Switzerland. This article is an open access article distributed under the terms and conditions of the Creative Commons Attribution (CC BY) license (http://creativecommons.org/licenses/by/4.0/). 